\title{
ANALIZA I RAZLIKE U BAZIČNO-MOTORIČKIM I SITUACIONO-MOTORIČKIM SPOSOBNOSTIMA RUKOMETAŠICA PRVE FEDERALNE LIGE I PRVE LIGE REPUBLIKE SRPSKE
}

\author{
Srđan Pavlović ${ }^{1}$, Munir Talović ${ }^{1}$, Elvir Kazazović ${ }^{1}$ i Rasim Lakota ${ }^{1}$ \\ ${ }^{1}$ Fakultet sporta i tjelesnog odgoja, Univerzitet u Sarajevu, Bosna i Hercegovina
}

\begin{abstract}
SAŽETAK
Osnovni cilj ovog istraživanja bio je utvrditi razlike u bazično-motoričkim i situaciono-motoričkim sposobnostima rukometašica. Istraživanje je urađeno na 77 rukometašice, seniorskog uzrasta iz Prve federalne lige BIH i Prve lige Republike Srpske.U prostoru bazično-motoričke sposobnosti korišteno je 18 varijabli koje su obuhvatale faktore za procjenu segmentarne brzine, fleksibilnosti, koordinacije, eksplozivne snage, repetitivne snage i ravnoteže. Situaciono-motorički prostor je posmatran i obuhvata pet hipotetskih latentnih faktora koji su odgovorni za situacionu efikasnost u rukometu: brzina baratanja sa loptom, preciznost, snaga izbačaja lopte, brzina kretanja bez lopte, baratanje loptom. $\mathrm{U}$ analiza kvantitativnih razlika na multivarijantnom nivou, diskriminativnom analizom, između Prve federalne lige BIH i Prve lige Republike Srpske u situaciono-motoričkim i bazično-motoričkim sposobnostima dobili smo da se nivoi takmičenja razlikuju odnosno da postoji statistička značajnost između tretiranih nivoa takmičenja. Dobijeni rezultati mogu doprinijeti boljem razumijevanju praćenja, analiziranja te boljem usavršavanju kondicijske i tehničko-taktičke pripreme rukometašica na različitim nivoima takmičenja, a sve u cilju postizanja većeg kvaliteta takmičenja seniroskih rukometašica u Bosni i Hercegovini.
\end{abstract}

Ključne riječi: bazična motorika i situaciona motorika, razlike, rukomet.

\section{UVOD}

Današnji moderni rukomet igra je izuzetno brzih, eksplozivnih i višestruko složenih pokreta, razvoja akcija, situacionih rješavanja problema, a koje sve zajedno obilježava nivo intenziteta aktivnosti što zahtijeva od igrača visok nivo sposobnosti, kako bazičnih tako specifičnih (Czerwinski, 1995; Đug, 2005).

Uticaj bazičnih motoričkih sposobnosti čini osnovu za daljnju nadogradnju specifičnih motoričkih sposobnosti koje su direktno odgovorne za postizanje kvalitetnih rezultata (Brčić, Viskić Štalec i Jaklinović Fressl, 1997; Demir, 2000). Postojanje pet latentnih situacijsko-motoričkih dimenzija u rukometu potvrđeno je od strane brojnih autora a to su: preciznost, baratanje loptom, brzina kretanja igrača s loptom, brzina kretanja igrača bez lopte i snaga izbačaja lopte.
Još su Kuleš i Šimenc (1983) istraživali uticaj bazičnih motoričkih sposobnosti na uspjeh u rukometu i utvrdili da eksplozivna snaga (horizontalne i vertikalne skočnosti te tipa bacanja), preciznost, brzina kretanja igrača sa i bez lopte te koordinacija definišu efikasnost rukometaša. U rukometu sve više dominiraju akcijska i reakcijska brzina, snaga, agresivnost, kao i univerzalnost igrača sa stanovišta pozicije u igri (Delija, Šimenc i Vuleta, 1995; Rogulj, 2000; Srhoj, Rogulj, Padovan i Katić, 2001; Vuleta, Milanović i Sertić, 2003).

Od igrača se zahtijeva poboljšanje sposobnosti izvođenja elemenata tehnike maksimalnim intenzitetom, razvoj agilnosti i eksplozivno-reaktivnog načina kretanja kako u napadačkim tako i u odbrambenim akcijama.

Uzimajući u obzir snažne udarce loptom napadača na gol, veliki broj snažnih duela igrača odbrane i napada po kojima je rukomet poznat, veliki broj skokova u odbrani i napadu, maksimalno brze kretnje 
igrača u kontranapadu i ostale faktore, pouzdano se može reći da je potrošnja energije na utakmici veoma visoka. To znači da je u rukometnoj igri u velikoj mjeri eksploatisana i energetska komponenta (Mujezinović, 2008; Vuleta, Milanović i Sertić, 1999).

Cilj ovog istraživanja je da na osnovu istraživanih prostora bazično-motoričkih i situaciono-motoričkih sposobnosti, utvrdimo razlike i nivo razlika rukometašica na različitim nivoima takmičenja.

\section{METODE}

\section{Uzorak entiteta}

Istraživanje je sprovedeno na uzorku od 77 rukometašica, seniorskog uzrasta, klinički zdravih. Sve ispitanice su rukometašice Prve federalne lige BIH i Prve lige Republike Srpske, registrovane u Rukometnom Savezu Bosne i Herzegovine. Definisanje motoričkog modela u ovom istraživanju izvršeno je na osnovu modela strukture motoričkih sposobnosti koje su definisali Kurelić i saradnici (1975).

\section{Uzorak varijabli}

U prostoru bazično-motoričkih sposobnosti korišteno je 18 varijabli. U prostoru situacionomotoričkih sposobnostii obuhvaćeno je pet varijabli.

Varijable za procjenu bazično- motoričkih sposobnosti:

- Taping rukom - MSBTAP,

- Taping nogom - MSBTAN,

- Pretklon- zasuk- dodir - MSBPZD,
- Iskret sa palicom - MFLISK,

- Duboki pretklon na klupici - MFDPK,

- Špagat - MFSPA,

- Stajanje na jednoj nozi sa zatvorenim očima MRRAV,

- Stajanje na obrnutoj klupici - MRSOK,

- Stajanje uzduž klupice za ravnotežu - MRSUK,

- Ispravljanje trupa - MRSIST,

- Dizanje trupa za 30 sekundi - MRSD30,

- Sklekovi - MRSSK,

- Koordinacija sa palicom - MKKOP,

- Slalom sa tri medicinke - MKS3M,

- 20 iskoraka sa palicom - MK2IP,

- Skok u dalj iz mjesta - MESDM,

- Bacanje medicinke (ležeći) na leđima - MFEBML,

- Vertikalni skok, sargent - MESVS.

Varijable za procjenu situaciono- motoričkih sposobnosti:

- Vođenje lopte u slalom - SMVLS,

- Gađanje loptom u cilj - SMGLC,

- Šutiranje loptom na daljinu iz koraka - SMŠLD,

- Trčanje u trouglu osnovnim odbrambenim stavom - SMTTOS,

- Šutiranje od zid 20 sekundi - SMŠZ20.

\section{Statistička analiza}

Razlike između rukometašica Prve federalne lige BIH i Prve lige Republike Srpske, za svaku primijenjenu varijablu su utvrđene diskriminativnom analizom.

\section{TABELA 1}

Boxov test.

\begin{tabular}{llr}
\hline Box's M & 530,977 \\
\hline F & Approx. & 1,286 \\
\cline { 2 - 3 } & $d f 1$ & 276,000 \\
\hline & $d f 2$ & 16520,816 \\
\hline$p$ & $\mathbf{0 , 0 0 1}$ \\
\hline
\end{tabular}

Legenda: $d f$ - Stepeni slobode; $p$ - Vjerovatnoća.

\section{TABELA 2}

Značajnost requltata diskriminativne funkeije.

\begin{tabular}{cccccccc}
\hline Eigenvalue & $\%$ of variance & Cumulative $\%$ & $R$ & $\lambda$ & $\chi^{2}$ & $d f$ & $p$ \\
\hline 2,753 & 100,0 & 100,0 & 0,856 & 0,266 & 83,976 & 23 & $\mathbf{0 , 0 0 0}$ \\
\hline
\end{tabular}

Legenda: Eigenvalue - Svojstvena vrijednost; \% of Variance - \% varijanse; Cumulative \% Kumulativni $\% ; \boldsymbol{R}$ - Kanonička korelacija; $\boldsymbol{\lambda}$ - Wilks' Lambda; $\chi^{2}$ - Hi kvadrat; $d f$ - Stepeni slobode; $p$ - Vjerovatnoća. 


\section{TABELA 3}

Matrica strukture diskriminacione funkcije:

\begin{tabular}{lc}
\hline & Function \\
\hline MRSIST & 0,346 \\
\hline SMGLC & $-0,277$ \\
\hline MK2IP & $-0,222$ \\
\hline MFDPK & $-0,185$ \\
\hline MKS3M & 0,180 \\
\hline SMTTOS & $-0,169$ \\
\hline MRSD30 & 0,160 \\
\hline SMVLS & 0,141 \\
\hline MFLISK & $-0,140$ \\
\hline ŠMLŠD & 0,129 \\
\hline MKKOP & $-0,127$ \\
\hline MFEBML & 0,127 \\
\hline MRSUK & $-0,120$ \\
\hline MRSOK & $-0,118$ \\
\hline MRRAV & $-0,095$ \\
\hline MRSSK & 0,091 \\
\hline MESSVS & 0,067 \\
\hline SMŠZ20 & 0,062 \\
\hline MSBTAP & 0,058 \\
\hline MSBTAN & 0,044 \\
\hline MSBPZD & 0,019 \\
\hline MESDM & 0,014 \\
\hline MFSPA & $-0,007$ \\
\hline &
\end{tabular}

Legenda: MSBTAP - Taping rukom; MSBTAN - Taping nogom; MSBPZD - Pretklon- zasuk- dodir; MFLISK - Iskret sa palicom; MFDPK - Duboki pretklon na klupici; MFSPA - Špagat; MRRAV - Stajanje na jednoj nozi sa zatvorenim očima; MRSOK - Stajanje na obrnutoj klupici; MRSUK - Stajanje uzduž klupice za ravnotežu; MRSIST - Ispravljanje trupa; MRSD30 - Dizanje trupa za 30 sekundi; MRSSK - Sklekovi; MKKOP - Koordinacija sa palicom; MKS3M - Slalom sa tri medicinke; MK2IP - 20 iskoraka sa palicom; MESDM - Skok u dalj iz mjesta;

MFEBML - Bacanje medicinke ležeći na leđima; MESVS - Vertikalni skok,sargent; SMVLS - Vođenje lopte u slalom; SMGLC - Gađanje loptom u cilj; SMSLD - Šutiranje loptom na daljinu iz koraka; SMTTOS - Trčanje u trouglu osnovnim odbrambenim stavom; SMSZ20 - Shooting against a wall for 20 seconds.

\section{REZULTATI I DISKUSIJA}

Analizirane su diskriminativne razlike između bazično-motoričkih i situaciono-motoričkih sposobnosti rukometašica Prve federalne lige $\mathrm{BiH}$ i Prve lige Republike Srpske.

U Tabeli 1 testirana je sličnost matrica kovarijansi između dva subuzorka (Rađo i Wolf, 2002) tj između ispitanica Prve federalne lige i Prve lige RS-a. Može se uočiti da je razlika matrica kovarijansi statistički značajna $(p=0,001)$ te dozvoljava pristup daljoj proceduri diskriminativne analize.

Analizirajući Tabelu 2 možemo vidjeti da je i u ovom prostoru došlo do kvantitativnih razlika kod ispitanica,što je i bilo očekivano. Vidimo da je došlo do formiranja jedne značajne diskriminativne funkcije visine 0,856 koja nam dokazuje u kojoj je korelaciji skup podataka na osnovu kojih smo vršili diskriminativnu analizu sa diskriminativnim funkcijama. 
$\mathrm{Na}$ osnovu rezultata strukture diskriminativne funkcije u Tabeli 3, može se uočiti da najveće korelacije sa diskriminativnom funkcijom, tj. sa varijablom koja maksimalno razlikuje vrijednosti rezultata bazičnomotoričkih i situaciono-motoričkih sposobnosti dva subuzorka imaju slijedeće varijable:

- Ispravljanje trupa koji propadaju prostoru repetativne snage. Značajan doprinos repetitivne snage prednjeg dijela trupa moguće je obrazložiti činjenicom što je snaga ove mišićne skupine osim za pregib trupa kod šutiranja i fintiranja, važna i za stabilizaciju trupa prijeko potrebnu kod čvrstih kontakata s protivnikom, ali ova mišićna skupina participira i u pregibanju natkoljenice, što posredno doprinosi učinkovitosti i brzini kretanja igrača sa i bez lopte.

- Gađanje loptom u cilj koji pripada prostoru preciznosti, a preciznost kao specifična motorička sposobnost ima velik udio u krajnjem rezultatu što se manifestira kroz sposobnost pogađanja nepokretne mete (gola) najčešće iz kretanja, ali $i$ iz statičke pozicije.

- 20 iskoraka sa palicom koji pripada prostoru koordinacije, koji pripadaju prostoru faktora za procjenu koodinacije koja predstavlja jednu, veoma kompleksnu motoričku dimenziju, i može se reći da je to jedan oblik motoričke inteligencije kod sportista-način razmišljanja o samom pokretu u vremenu i prostoru, način njegove interpretacije, brzine izvođenja i brzine učenja nove motorne akcije.

\section{TABELA 4}

Centroidi grupa.

\begin{tabular}{cc}
\hline Group & Function \\
\hline 1 & $-1,747$ \\
\hline 2 & 1,534 \\
\hline
\end{tabular}

Analizom rezultata u Tabeli 4 može se uočiti da se prva grupa ispitanika tj. rukometašice Prve federalne lige $\mathrm{BiH}$, nalaze u negativnom dijelu diskriminativne funkcije, čime je definišu varijable koje imaju negativan uticaj na diskriminativnu funkciju. Druga grupa ispitanika čine rukometašice Prve lige Republike Srpske koje se nalaze u pozitivnom dijelu diskriminativne funkcije, čime su definisane varijable koje imaju pozitivan uticaj na diskriminativnu funkciju.

\section{ZAKLJUČAK}

Rezultati ovog istraživanja pokazuju da se rukometašice različitog nivoa takmičenja statistički značajno razlikuju u bazično motoričkim i situaciono motoričkim sposobnostima.

Objašnjenje postojanja razlika između rukometašica različitih nivoa takmičenja je prije svega u nivou takmičenja. Prve federalne lige BIH imaju znatno bolju motivaciju jer imaju jasnu pomoć i podršku $\mathrm{RSBiH}$, samim tim i ozbiljno definisanu karijeru. Kao što je poznato psihološki aspekt je veoma važan u sportu. Drugi razlog postojanja razlika se može posmatrati sa aspekta dizajniranih treninga za seniorke. Treći razlog postojanja razlika je u nivou mentalne,kondicijske i tehničko taktičke pripreme seniorki. Dobiveni rezultati mogu doprinijeti boljem razumijevanju praćenja,analiziranja te boljem usavršavanju kondicijske i tehničko-taktičke pripreme rukometašica na različitim nivoima takmičenja, a sve u cilju posti- zanja većeg kvaliteta takmičenja rukometašica za seniorke u Bosni i Hercegovini.

\section{LITERATURA}

Brčić, B., Viskić Štalec, N., \& Jaklinović Fressl, Ž. (1997). Prediktivna vrijednost varijabli za procjenu tehničko-taktičkih elemenata u rukometu [Predictive value of variables for the evaluation of technical-tactical elements in handball]. Kinesiology, 1(29), 60-70.

Czerwinski, J. (1995.). The influence of technical abilities of players on the tactical selection in the handball game. European Handball, 2, 16-19.

Delija, K., Šimenc, Z., \& Vuleta, D. (1995). Razlike u nekim općim i situacijskim testovima motoričkih sposobnosti rukometaša i onih koji ne igraju rukomet [Differences in some general and situation tests of motor abilities in handball player and those not play handball]. Kinesiology, 27(1), 57-61.

Demir, M. (2000). Kanonickki odnos morfoloških dimeñija i situacijsko-motion sposobnosti s mladim rukometasima [Canonic relation between morphological dimensions and situationalmotion abilities with young handball players]. Unpublished master's thesis, University of Sarajevo, Faculty of Sport and Physical Education. 
Đug, M. (2005). Efikeasnost različitih metoda za poboljsanje sakakačkih sposobnost rukometaša Efficiency of different methods for improvement of handball players jumping ability]. Unpublished master's thesis, University of Tuzla, Faculty of physical education and sport.

Kuleš, B., \& Šimenc, Z. (1983). Odnos između različitih motoričkih sposobnosti i efikasnosti u rukometu [Relationship between different motor abilities and efficiency in handball]. Kinesiology, 15(2), 153-163.

Kurelić, N., Momirović, K., Stojanović, M., Šturm, J., Radojević, Đ, \& Viskić-Štalec, N. (1975). Struktura i avluacija morfoloških i motornih dimenzije omladine [The Structure and evolution of morphological and motor dimensions of youth]. Belgrade, RS: Instititu za naučna istraživanja Fakulteta fizičke kulture.

Mujezinović, M. (2008). Uticaj programiranog treninga na specijalne $i$ bazične motoričke sposobnosti u rukometu [Effects of programmed training on special and basic motor abilities in handball]. Unpublished master's thesis, University of Sarajevo, Faculty of Sport and Physical Education.

Rađo, I., \& Wolf, B. (2002) Metode kvantifikacije u sportu [Methods for quantification in sport].
Sarajevo, BA: Faculty of Sport and Physical culture.

Rogulj, N. (2000). Razlike u rukometnim situacionim indikatorima u odnosu na postignute rezultate takmičarskih ekipa na Svetskom prvenstvu 1999 u Egiptu [Differences in situation-related indicators of the handball game in relation to the achieved competitive results of teams at 1999 World Championship in Egypt]. Kinesiology, 32(2), 63-74.

Srhoj,V., Rogulj, N. Padovan, M., \& Katić R. (2001). Influence of the attack end conduction on match result in handball. Collegium antropologicum, 25(2), 611-617.

Vuleta, D., Milanović, D., \& Sertić, H. (1999). Latentna struktura prostornih, faznih, pozicijskih i kretnih karakteristika rukometne igre [Latent structure of the spatial, phasic, positional and movement characteristics of the handball game]. Kinesiology, 31(1), 37-53.

Vuleta, D., Milanović, D., \& Sertić, H. (2003). Odnosi između varijabli šuta na gol i rezultata na utakmicama muškog Europskog rukometnog prvenstva 2000 [Relations among variables of shooting for a goal and outcomes of the 2000 Men's European Handball Championship matches]. Kinesiology, 35(2), 168-183.

Primljeno: 21 oktobra, 2013

Izmjene primljene: 12 nivembra, 2013

Odobreno: 21 decembra, 2013

Korespodencija: Mr Srđan Pavlović Fakultet sporta i tjelesnog odgoja Patriotske lige 41 71000 Sarajevo Bosna i Hercegovina Telefon: 0038765646163 E-mail: srdjanpavlovic1984@hotmail.com 